\title{
Perbandingan Estimasi Laju Filtrasi Glomerulus Berdasarkan Formula Cockroft-Gault dengan Estimasi Laju Filtrasi Glomerulus Berdasarkan Formula Chronic Kidney Disease Epidemiology Collaboration pada Subyek Penyakit Ginjal Kronik Non-Dialisis Periode Januari - Desember 2017
}

\author{
${ }^{1}$ Fricilia Y. Kaitang \\ ${ }^{2}$ Emma Sy. Moeis \\ ${ }^{2}$ Maarthen C. P. Wongkar
}

${ }^{1}$ Program Studi Pendidikan Dokter Fakultas Kedokteran Universitas Sam Ratulangi Manado

${ }^{2}$ Bagian Ilmu Penyakit Dalam Fakultas Kedokteran Universitas Sam Ratulangi Manado

Email: pricilia_kaitang@yahoo.com

\begin{abstract}
Chronic kidney disease (CKD) is one of the health problems worldwide. Evaluation of kidney function could be done by measuring and calculating glomerular filtration rate (GFR). The direct measurement of GFR using exogenous or endogenous substance is difficult to be performed and inconvenience, therefore, the estimation of GFR (eGRF) is more preferable. The eGRF is used for assessing the grades of kidney diseases and their underlying mechanisms. Meanwhile, determination of eGRF is based on the formula of Cockroft-Gault $\left(\mathrm{eGRF}_{\mathrm{CG}}\right)$ and the formula of Chronic Kidney Disease Epidemiology Collaboration (eGRF $\mathrm{CKD}_{\mathrm{C}-}$ EPI). This study was aimed to evaluate the difference between the $\mathrm{eGRF}_{\mathrm{CG}}$ and $\mathrm{eGRF}_{\mathrm{CKD}-\mathrm{EPI}}$ among non-dialysis CKD patients. The results showed that there was a confirmity of $79.2 \%$ between the two formulas. The gamma test obtained an $\mathrm{r}$ of $0.873(P<0.01)$ for the two formulas. Conclusion: There was a confirmity of $79.2 \%$ between the eGFR formula of Cockroft-Gault and the eGFR formula of Chronic Kidney Disease Epidemiology Collaboration among non-dialysis CKD patients.
\end{abstract}

Keywords: CKD, eGFR CG, eGFR CKD

\begin{abstract}
Abstrak: Penyakit ginjal kronik (PGK) merupakan salah satu masalah kesehatan dunia. Penilaian fungsi ginjal dapat dilakukan dengan cara pengukuran dan perhitungan laju filtrasi glomerulus (LFG). Pengukuran LFG secara langsung dengan substansi eksogen atau endogen pada pelaksanaannya sulit dan tidak praktis sehingga saat ini digunakan perhitungan estimasi LFG (eLFG). Estimasi LFG digunakan untuk menilai stadium gangguan ginjal dan perjalanan penyakit ginjal. Penentuan estimasi LFG berdasarkan rumus formula eLFG Cockroft-Gault $\left(\mathrm{e} \mathrm{LFG}_{\mathrm{CG}}\right)$ dan formula eLFG dari Chronic Kidney Disease Epidemiology Collaboration

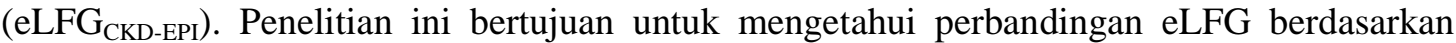
eLFG CG dengan eLFG CKD EPI $_{\text {pada }}$ PGK non-diaisis (PGK ND). Hasil penelitian mendapatkan adanya kesesuaian dari kedua formula eLFG sebesar 79,2 \%. Hasil uji Gamma mendapatkan hasil kesesuaian eLFG Cockroft-Gault dengan eLFG CKD $D_{\text {EPI }}$ dengan $r=0,873$ $(P<0,01)$. Simpulan: Terdapat kesesuaian sebesar $79,2 \%$ dari hasil pemeriksan eLFG berdasarkan formula eLFG Cockroft-Gault dengan formula eLFG CKD ${ }_{\mathrm{EPI}}$ pada penderita PGK non dialisis.
\end{abstract}

Kata kunci: PGK, eLFG CG, eLFG CKD $\mathrm{EPI}$ 
Menurut definisi dari Kidney Disease: Improving Global Outcome (KDIGO), penyakit ginjal kronik (PGK) adalah gangguan pada struktur atau fungsi ginjal lebih dari tiga bulan, dengan implikasi kesehatan yang diklasifikasikan berdasarkan etiologi, klasifikasi laju filtrasi glomerulus, dan albuminuria. ${ }^{1}$

Penyakit ginjal kronik merupakan salah satu masalah kesehatan dunia. Hasil penelitian Global Burden of Disease tahun 2010 melaporkan bahwa PGK merupakan penyebab kematian ke-27 di dunia dan meningkat menjadi urutan ke-18 pada tahun 2010. ${ }^{2}$ Menurut National Institute of Diabetes and Digestive and Kidney Diseases (NIDDK), $10 \%$ orang dewasa di Amerika memiliki PGK dan terus meningkat dalam 10 tahun terakhir. ${ }^{3}$ Data di Amerika United States Renal Data System (USRDS) tahun 2015 menyatakan tingkat mortalitas PGK pada laki-laki 120 per 1000 pasien per tahun dan pada perempuan 103 per 1000 pasien pertahun. ${ }^{3}$ PGK merupakan penyebab utama kematian kesembilan di Amerika Serikat. ${ }^{4}$ Berdasarkan data riset kesehatan masyarakat dasar (Riskesdas) tahun 2013 pravalensi gagal ginjal kronik di Indonesia sebesar 0,2\% dengan pravalensi terendah $1 \%$ dan tertinggi $4 \%$. Riskesdas mengemukakan terdapat tiga provinsi dengan pravalensi tertinggi di Indonesia yaitu Sulawesi tengah $0,5 \%$, Aceh $0,4 \%$, Gorontalo 0,4\%, dan Sulawesi Utara $0,4 \% .^{5}$

Gambaran klinis PGK sesuai dengan penyakit yang mendasari seperti diabetes melitus, infeksi traktus urinarius, hipertensi, hiperurikemi, lupus eritematosus sistemik (LES), dan lain sebagainya. Pada pasien dengan PGK dapat dijumpai juga sindrom uremia yang terdiri dari lemah badan, letargi, anoreksia, mual-muntah, nokturia, kelebihan volum cairan (volume overload), neuropati perifer, pruritus, uremic frost, perikarditis, kejang-kejang sampai koma. Juga terdapat gejala komplikasi antara lain, hipertensi, anemia, osteodistrofi renal, payah jantung, asidosis metabolik, ganguan keseimbangan elektrolit (sodium, kalium, dan klorida). ${ }^{6}$
Penilaian fungsi ginjal dapat dilakukan dengan cara pengukuran laju filtrasi glomerulus (LFG) dan penghitungan LFG. Pengukuran LFG secara langsung dengan substansi eksogen atau endogen pada pelaksanannya sulit dan tidak praktis sehingga saat ini digunakan perhitungan estimasi LFG (eLFG). Estimasi LFG (eLFG) digunakan untuk menilai stadium gangguan ginjal dan perjalanan penyakit ginjal. Penentuan estimasi LFG berdasarkan rumus formula estimasi laju filtrasi glomerulus Cockroft-Gault (eLFG ${ }_{\mathrm{CG}}$ ), dan berdasarkan formula estimasi laju filtrasi glomerulus dari Chronic Kidney Disease Epidemiology Collaboration (eLFG ${ }_{\mathrm{CKD}}$ EPI). ${ }^{7}$ Pada persamaan estimasi LFG Cockroft-Gault pelaksanaannya sangat mudah dan praktis dilakukan di klinis. Namun, memiliki keterbatasan yaitu kurang akurat untuk LFG di atas $60 \mathrm{ml} / \mathrm{menit}$, individu dengan berat badan berlebih atau obesitas, dan yang dengan usia $>70$ tahun. Persamaan estimasi laju filtrasi glomerulus Chronic Kidney Disease Epidemiology Collaboration merupakan persamaan eLFG yang paling akurat dan telah dievaluasi pada populasi beragam dalam jumlah besar dan dapat diterapkan pada penggunaan klinis secara umum

Penelitian ini bertujuan untuk mengetahui perbandingan gambaran eLFG berdasarkan rumus formula Cockroft-Gault (eLFG ${ }_{\mathrm{CG}}$ ) dengan eLFG Chronic Kidney Disease Epidemiology Collaboration

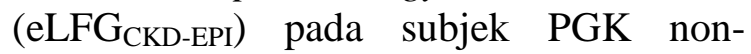
dialisis periode Januari-Desember 2017 di Poliklinik Rawat Jalan Ginjal-Hipertensi RSUP Prof. Dr. R. D. Kandou Manado.

\section{METODE PENELITIAN}

Penelitian yang dilakukan bersifat analitik dengan menggunakan data rekam medik Poliklinik Rawat Jalan GinjalHipertensi RSUP Prof. Dr. R. D. Kandou.

Sampel penelitian yaitu semua pasien PGK non-dialisis (stadium 3-5) periode Januari-Desember 2017. Kriteria inklusi dalam penelitian ini ialah pasien PGK non dialisis dengan data identitas lengkap yaitu PGK 3, 4, dan 5 non dialisis dengan usia 
$<60$ tahun. Kriteria ekslusi ialah pasien PGK dengan identitas tidak lengkap.

Data hasil penelitian dianalsis dengan mnggunakan program komputer. Analisis dalam bentuk tabel distribusi untuk data kategori sedangkan untuk data numerik dinyatakan dalam bentuk rerata, SD, nilai terendah, dan tertinggi. Uji statistik menggunakan analisis korelasi gamma karena data dalam bentuk stadium PGK.

\section{HASIL PENELITIAN}

Setelah dilakukan pengambilan data, didapatkan 95 pasien PGK-ND pada periode Januari-Desember 2017. Dari 95 pasien, hanya 48 pasien yang memenuhi kriteria inklusi dan ekslusi penelitian. Tabel 1 memperlihatkan bahwa distribusi formula eLFG CG dengan stadium PGK 3 sebanyak 20 orang $(41,67 \%)$, PGK 4 sebanyak 20 orang $(41,67 \%)$, dan PGK 5 sebanyak 8 orang $(16,66 \%)$.

Tabel 1. Distribusi formula eLFG CockroftGault berdasarkan stadium PGK

\begin{tabular}{ccc}
\hline Stadium PGK & N & \% \\
\hline PGK 3 & 20 & 41,67 \\
PGK 4 & 20 & 41,67 \\
PGK 5 & 8 & 16,66 \\
Total & 48 & 100 \\
\hline
\end{tabular}

Tabel 2 menunjukkan bahwa distribusi eLFG CKD EPI dengan stadium PGK 3 sebanyak 17 orang $(35,42 \%)$, PGK 4 sebanyak 25 orang $(52,08 \%)$, dan PGK 5 sebanyak 6 orang $(12,5 \%)$

Tabel 2. Distribusi eLFG CKD EPI berdasarkan stadium PGK

\begin{tabular}{ccc}
\hline $\begin{array}{c}\text { Stadium } \\
\text { PGK ND }\end{array}$ & N & $\begin{array}{c}\text { Persentase } \\
(\mathbf{\%})\end{array}$ \\
\hline PGK 3 & 17 & 35,42 \\
PGK 4 & 25 & 52,08 \\
PGK 5 & 6 & 12,5 \\
Total & 48 & 100 \\
\hline
\end{tabular}

Tabel 3 menunjukkan bahwa hasil uji kesesuaian eLFG CG dan eLFG CKD EPI dalam bentuk derajat yang diuji dengan analisis korelasi Gamma sebab data dalam bentuk kategori ordinal. Hasil uji mendapatkan $\mathrm{r}_{\mathrm{G}}=0,873$ dengan $P<0,01$, yang menunjukkan bahwa terdapat kesesuaian yang sangat kuat dari hasil pemeriksaan kedua alat estimasi ini dalam mengukur LFG. Kesesuaian ini nampak pada kategori yang sama, yakni dari 48 subjek sebanyak 38 pasien yang sama atau 38/48 $=79,2 \%$.

Tabel 3. Uji kesesuaian hasil pemeriksaan eLFG CG dengan eLFG CKD EPI berdasarkan stadium

\begin{tabular}{cccccc}
\hline eLFG & \multicolumn{3}{c}{ eLFG } & & $\begin{array}{c}\text { Uji } \\
\text { CKD EPI }\end{array}$ \\
& 3 & 4 & 5 & Total & $\begin{array}{c}\text { Korelasi } \\
\text { gamma }\end{array}$ \\
\hline 3 & 14 & 6 & 0 & 20 & \\
4 & 2 & 18 & 0 & 20 & $\mathrm{r}=0,873$ \\
5 & 1 & 1 & 6 & 8 & $(P<0,01)$ \\
Total & 17 & 25 & 6 & 48 & \\
\hline
\end{tabular}

\section{BAHASAN}

Berdasarkan penelitian yang dilakukan di Poliklinik Ginjal dan Hipertensi RSUP Prof. Dr. R. D. Kandou Manado periode Januari-Desember 2017 diperoleh 95 sampel dengan PGK ND. Dari 95 sampel tersebut, hanya 48 sampel yang memenuhi kriteria inklusi dan ekslusi penelitian.

Filtrasi glomerulus adalah proses fisiologis untuk menciptakan ultrafiltrasi darah saat melalui kapiler glomerulus. LFG dipengaruhi oleh berbagai kondisi fisiologik dan patologik yang bervariasi. Persamaan CKD-EPI merupakan persamaan eLFG paling akurat yang telah dievaluasi pada populasi beragam dalam jumlah besar dan dapat diterapkan pada penggunaan klinis secara umum. ${ }^{23}$

Pada penelitian ini didapatkan distribusi eLFG berdasarkan formula eLFG CG dengan persentase yang sama antara PGK stadium 3 dan 4 yaitu 41,67\% sedangkan PGK 5 sebesar 16,67\% (Tabel 1). Pada distribusi eLFG berdasarkan formula eLFG CKD EPI didapatkan persentase PGK 3 sebesar 35,42\%, PGK 4 sebesar 52,08\%, dan PGK 5 sebesar 12,5\% (Tabel 2). Berdasarkan hasil uji kesesuaian eLFG CG dan eLFG CKD EPI dengan analisis 
korelasi Gamma diperoleh $\mathrm{r}_{\mathrm{G}}=0,873$ $(P<0,01)$, yang menunjukkan kesesuaian yang sangat kuat dari kedua alat estimasi ini dalam mengukur LFG (Tabel 3). Kesesuaian ini nampak pada kategori yang sama, yakni dari 48 subjek sebanyak 38 pasien yang sama atau 38/48 $=79,2 \%$.

Pada penelitian Dewi ${ }^{8}$ terhadap performa eLFG dinyatakan hal yang sama yaitu eLFG CG dan eLFG CKD EPI memiliki performa yang hampir sama. Penelitian yang dilakukan oleh Michaels et $\mathrm{al}^{9}$ mengenai performa kinerja CockcroftGault, MDRD, dan formula CKD EPI baru terkait dengan GFR, usia, dan ukuran tubuh melaporkan bahwa CKD EPI memberikan eLFG terbaik dibandingkan dengan Cockcroft-Gault karena masih dipengaruhi oleh berat badan dan BMI. Williams et al ${ }^{10}$ menyatakan bahwa eLFG CG memberikan hasil yang lebih rendah dibandingkan eLFG CKD EPI untuk usia $>70$ tahun, namun memberikan gambaran yang lebih baik pada CKD dengan usia $<70$ tahun.

Hasil penelitian ini menunjukkan bahwa formula eLFG Cockroft-Gault tidak berbeda bermakna dengan formula eLFG CKD EPI pada penderita PGK-ND di RSUP Prof. Dr. R. D. Kandou Manado.

\section{SARAN}

Disarankan untuk melakukan penelitian lanjut pada penderita PGK ND dengan jumlah sampel yang lebih besar untuk mengetahui perbandingan eLFG berdasarkan formula eLFG Cockroft-Gault dengan formula eLFG CKD EPI.

\section{SIMPULAN}

Berdasarkan hasil penelitian ini maka disimpulkan bahwa terdapat kesesuaian sebesar 79,2\% dari hasil pemeriksan eLFG berdasarkan formula eLFG Cockroft-Gault dengan formula Chronic kidney Disease Epidemiology Collaboration pada penderita CKD non dialisis stadium 3,4, dan 5.

\section{DAFTAR PUSTAKA}

1. KDIGO CKD Work Group. KDIGO 2012 Clinical Practice Guideline for the Evaluation and Management of Chronic Kidney Disease. Kidney International Supplements. 2013;3(1): 1-150.

2. Kementerian Kesehatan RI. 2017. Infodatin Pusat Data Informasi Kementerian Kesehatan RI.

3. United States Renal Data System. Chapter 1: CKD in the General Population. 2015. USRDS annual data report: epidemiology of kidney disease in the United States. Bethesda MD: National Institute of Diabetes and Digestive and Kidney Diseases, 2015.

4. Centers for Disease Control and Prevention. Deaths and Mortality. [cited 2018 Jan 8]. Available from: http://www.cdc. gov/nchs/fastats/deaths. htm. May 3, 2017.

5. Badan Penelitian dan Pengembangan Kesehatan Kementrian Kesehatan RI. Riset Kesehatan Dasar. 2013: p. 94-6.

6. Suardjono, Lydia A, et al. Gagal ginjal kronik. In: Buku Ajar IlmuPenyakit Dalam Jilid II (3rd ed). Jakarta: FKUI, 2009; p. 427-37.

7. Simon J, Amde M, Poggio ED. Interprenting the estimated glomerular filtration rate in primary care; benefits and pitfalls. Clev Clin J Med. 2011;78(3): 189-95.

8. Dewi PY. Performa formula Cockroft-Gault, MDRD dan CKD-EPI. Yogyakarta: FK UGM, 2014.

9. Michaels WM, Grootendorst DC, Verduijn M, Elliot EG, Dekker FW, Krediet RT. Performance of the CockcroftGault, MDRD, and New CKDEPI Formulas in relation to GFR, age, and body size. Clin J Am Soc Nephrol. 2010;5(6):1003-9.

10. Williems JM, Vlasveld T, den Elzen WPJ, Westendorp RGJ, Rabelink TJ, de Craen AJM, et al. Performance of the Cockcroft-Gault, MDRD, and CKD EPI in estimating prevalence of renal function and predicting survival in the oldest old. BMC Geriatr. 2011;13:113. 